ELK

Asia Pacific Journals

www.elkjournals.com

\title{
CUSTOMER PERCEPTION TOWARDS HOME LOAN WITH SPECIAL REFERENCE TO SBI- A STUDY
}

\author{
Manjula Bai H \\ Faculty Member \\ Dept of Post Graduate Studies and Research in Commerce \\ Kuvempu University \\ Shankaraghatta \\ manjularaikar76@gmail.com \\ $\mathrm{Ph}: 9886219292$
}

\begin{abstract}
The present paper provides a platform to understand the prospects and problems of Housing Finance faced by an individual while dealing with a Home loan. So in order to collect this information a researcher has selected 50 respondents who have availed Home loan of SBI bank in various branches in Shimoga. It particularly focused on the problems or the benefits availed from the housing loan provided by SBI bank. All levels of customers were surveyed by using questionnaire and the level of satisfaction or dissatisfaction from the loan availed was studied. Finally the detail information about the benefits they had received were also considered. A small attempt have been made to understand the benefits of the home loan and also the level of stress the individual faced while clearing the loan was studied with reference to SBI Bank. Finally, it makes an attempt to offer suggestions to Banks to improvise the procedure of the loan proceedings.
\end{abstract}

Keywords- Loan Default, Loan Category, Inter Loan Default, Loan Category, Interest Rate, EMI, Sarfaesi Act.

\subsection{INTRODUCTION}

House is where the heart owes a home and is a lifelong dream for most of the people.Home is more or less a life time investment and home loans are in integrate part of every person. A first priority for youngster who begins life, is there for to plan for a house. Buying a house is dream for everyone. Owing to the rising price of Properties, it has almost become impossible for an average earning person to buy a house on a lump sum payment. Loan is offered to a borrower to purchase or build a new house on the basis of 
ISSN 2349-2325 (Online); DOI: 10.16962/EAPJFRM/issn. 2349-2325/2015; Volume 9 Issue 4 (2018)

his/her eligibility and the bank's lending rules. House is the ultimate dream of every middle class family. Government gave encouragement for house finance subsidiaries by offering number of tax concessions to individuals, with the overall encouragement given to this sector, a number of players entered in housing finance.

One of the most important benefits of taking a housing loan is the interest rate that is allowed on the housing loan. Fixed and variable interest rate options are also available for housing loans. Many financiers also offer house improvement loans at the same interest rate as they offer the housing loans.

The urban population of India has been growing at a rapid pace. As per the census 2011, 31.16\% of the total Population is in the urban areas. According to FICCI'S report (October 2011) 900 million people will be added to Indian cities by 2050 . In addition to it, the present upswing in economic growth of India has caused increasing buying power of Indian consumers, so has boosted the real estate market.

In pursuance of National Housing Policy of Central Government, Reserve Bank of India has been facilitating the flow of credit to housing sectors. Since it has emerged as one of the sectors attracting a large quantum of bank finance, the current focus of RBI's regulation is to ensure orderly growth of housing loan portfolios of banks.

A person can generally seek a first time home loan for buying a house or a flat, renovation, extension and repairing to his/her existing house. Indians with a regular source of income which includes salaried individuals, self-employed professionals, self-employed business people, NRI individuals and existing property owners who can pledge it as security for the loan. These are all eligible for a housing loan. The individuals applying for the loan should be above 21 years of age when the loan period begins and should be less than 65 years, when the loan period closes. By taking a housing loan from a bank, the borrower pledges his/her home as the lender's security (mortgage) for repayment of the loan.

\subsection{REVIEW OF LITERATURE}

A good number of research works have been undertaken by individual researchers and institutions invariably dealing with different aspects of housing finance. Several studies have been done by various researchers in the context of 
ISSN 2349-2325 (Online); DOI: 10.16962/EAPJFRM/issn. 2349-2325/2015; Volume 9 Issue 4 (2018)

housing loans. The details of reviews are below:

De Paul Singh (2001) in his study entitled "Consumer Behaviour and Bank Retail products an Analysis "stresses that, the borrower attitude is an important factor for the improvement of housing loan schemes".

H DrRangarajan C (2001) said that, "the financial system of India built a vast network of financial institutions and markets over times and the sector is dominated by banking sector which accounts for about two-third of the assets of organised financial sectors".

P.K.Manoj (2004), examined on the growth and development of housing finance system in India. $\mathrm{He}$ also emphasized the importance of housing to the economy and prospects of housing finance industry. He found the risk factors and issues involved in aggressive lending to housing due to cut-throat competition, and the peculiar features of the existing regulatory and legal system. And he suggested that measures should be taken to promote active mortgage backed securitization market in India, which can further strengthen our housing finance system and make it more competitive.
Housing Policy Department, NABH (2009) in a study examined the local impact of home building in a typical metro area. According to this study house building generates various local activities like job for local residents and revenue for the local governments. A model developed by National Association of Home Builders to estimate the economic benefits. This model was applied to construction in over 500 projects, local jurisdiction, and states across the country. The results of the model showed that house building produce impacts income and employment of the country.

\section{Favilukis, Ludvigson and Nieuwerburgh}

(2011) examined the macroeconomic effects of housing wealth, housing finance and limited risk sharing in general equilibrium. The study examined a twosector general equilibrium model of housing and non-housing production. Because of limited financial market, households face limited risk sharing opportunities. Home prices declined in 2007 because of economic contraction. The model showed that pro cyclical increased in equilibrium price rent

Tiwana, Jasmine and Singh, Jagpal (2012), In their paper they discussed about the regulatory aspects pertaining to 
ISSN 2349-2325 (Online); DOI: 10.16962/EAPJFRM/issn. 2349-2325/2015; Volume 9 Issue 4 (2018)

housing finance companies in the light of

various directions and guidelines issued by

National Housing Bank.

Garg, Dr. Shiv Kumar and Kumar, Dr.Gajendra (2014), reported in their paper that due to bank reforms, government encouraged banking sectors to identify housing finance sector and its importance in lending. They stated that Housing finance sector is the fastest growing segment of the retail financing sector. The paper resulted out that agencies of Public sector housing finance companies, Private sector housing companies and banks are competitors in housing finance market.

Shankar, E. (2014), observed that the population is striving hard to find a shelter in our country so commercial banks have been continuously directed to Finance the housing Schemes launched by Central and State Governments. In his paper he attempted to study the role played by Scheduled Commercial Banks in meeting the housing financial requirements at Macro level..The role of Scheduled commercial banks have been clearly analysed and its significance in providing housing finance has been stated.

\subsection{OBJECTIVES OF THE STUDY}

Housing loans have become those stronger foundations for people who want to own a house. The main objectives of the study are as follows:-

1. To study the satisfaction level of customers about home loans.

2. To study the problems faced by customers in obtaining the home loans.

3. To know the ideas of customers about home loan products and services.

4. To know about customers response regarding the home loans.

5. To know various rates available while providing home loans

6. To analyse various methods of operating a home loan.

7. To analyse the impact of home loan, when it becomes default.

\subsection{Methodology of the study}

\section{> 1.6. METHODOLOGY:}

\section{$>$ Research Design:}

Research refers to the systematic method consisting of enunciating the problems. Formulating a hypothesis, collecting the facts or data. Analyzing the facts and reaching certain conclusions either in the form of solutions towards the concerned problem or in certain generalizations for some theoretical formulation. The study is descriptive is nature, thus it factors descriptive research design. 
ISSN 2349-2325 (Online); DOI: 10.16962/EAPJFRM/issn. 2349-2325/2015; Volume 9 Issue 4 (2018)

$>$ Universe:

The universe of the study consists of all the private and public sector banks operating in India.

\section{> Sampling method:}

The sample to be studied is selected through multi stage sampling. Firstly the private and public sector banks are chosen on the basis of convenience sampling, secondly, branches to be studied are chosen through cluster method.

\section{$>$ Sample unit:}

The study will collect information on customer perception towards home laon with special reference to SBI Bank from Shimoga region.

\section{Collection of Data}

In order to meet the objectives of the study, the required data have been collected from primary and secondary sources.

\section{$>$ Primary Data}

The primary data has been collected through the structured questionnaires. The questionnaires have been issued to those respondents who are having account and taking loans in SBI branches in Shimoga.

\section{$>$ Secondary Data}

The secondary data are collected from various sources, used in addition to the primary data in the research. The various sources of secondary data are Internet, Newspapers, Reports, Company websites, Magazines and Books.

\section{> Sample size}

For the purpose of conducting these study 50 respondents has been taken.

\section{Analysis of data:}

- Data so collected will be tabulated suitably for the purpose of the analysis.

- Appropriate statistical tools like chi-square will be used for the analysis and interpretation of data.

\subsection{Need for the study}

Eventhough people are availing loan and have their dreams fulfilled of having a Home, there are many problems faced by them even after availing the loan. So this study is undertaken to understand the level of satisfaction or dissatisfaction from the loan availed .Finally the detail information about the benefits they had received are also considered.

\subsection{Statement of the Problem}

The Constitution of India recognizes the right to live and have a livelihood as a fundamental right. This includes the right to housing policy. Housing demand is a universal problem, being one of the prime 
ISSN 2349-2325 (Online); DOI: 10.16962/EAPJFRM/issn. 2349-2325/2015; Volume 9 Issue 4 (2018)

necessities of life. Food and clothing

which are the other two prime requirements have been met to some extent. However housing demand still needs to be fulfilled. This is because of the shortage of funds and inadequacy of financial institutions, coupled with an increase in building material, labour and other costs.

In this way, various Banks provide a housing finance. But some people are facing problems on getting the home loans. Hence this study made an attempt to know , what are the problems faced by an individual and try to solve these problems by providing suitable solutions.

\subsection{Scope of the study}

The scope of the study is restricted to Branches of SBI in Shimoga only. This study covers the eligible conditions, operations, disbursement and repayment of loans, home loans schemes, interest rate and the terms provided. This study focus on only home loan services.

\subsection{LIMITATIONS OF THE STUDY}

1. The scope of the study is confines to the branches of SBI bank in shimoga only.

2. The study only concentrated understanding and analysing home loan service provided by SBI bank
3. The sample size is only 50. So it cannot represent the entire population.

4. Not all responds answers are true and fare which are given by customers.

\subsection{SBI HOUSING LOAN}

SBI Housing Loan or Mortgage Loan schemes are designed to make it simple to take a choice at least as far as financing goes.

\subsection{Features of SBI Home Loan}

$>$ No cap on maximum loan amount for purchase/construction of house/flat.

$>$ Repayment permitted up to 70 years of age.

$>$ Options to club income of your spouse and children to compute eligible loan amount.

$>$ Free personal accident insurance cover.

> Interest applied on daily diminishing balance basis.

> 'Plus' schemes which offer attractive package with concessional interest rates to Government Employees, Teachers, Employees in public sector oil companies.

$>$ No administrative charges or application fee. 
ISSN 2349-2325 (Online); DOI: 10.16962/EAPJFRM/issn. 2349-2325/2015; Volume 9 Issue 4 (2018)

$>$ Option to avail loan at the place of employment or at the place of construction.

$>$ Provision to club expected accruals from property proposed to compute eligible loan amount.

$>$ Provision to finance cost of furnishing and consumer durables as part of project cost.

> Special scheme to grant loans to finance Earnest Money Deposit to be paid to Urban Development Authority/Housing board, etc. in respect of allotment of sites/house/flat.

\subsection{HOME LOAN CATEGORIES}

We can find home loans of two categories. They are depending on the interest rate regime offered by various banks, these are as follows:

\section{1) Fixed Interest Rate Loans}

Under this type of home loan, bank charges the same amount of interest rate throughout the tenure of loan. However the disadvantage is that borrower is subject to market risk. Generally, fixed interest rate loans are costlier than floating interest rate loans. Availing this type of loan facility is beneficial only when there is expectation that the interest rates will have an upward revision in the near future.

\section{2) Floating Interest Rate Loans}

Floating interest rate home loans are subject to market conditions and hence they are constantly revised by the banks. These loans are generally called as "adjustable rate home loans" as the interest rates vary throughout the entire tenure. Floating rates are beneficial only if the interest rates fall in the future. The lender charges a lower rate for such loan because they are taking on some of the interest rate risk.

\section{3) Other costs}

Apart from paying interest rate and EMIs there are several other costs which need to be borne by the customer while taking up the home loan facility. Recently, the banks have made it mandatory for the borrowers of the loan amount to get the home, insured in order to safeguard their interest. There is other costs factor like processing fee, administration fee, valuation fee, legal fee etc. which needs to be paid at the time of application.

\subsection{MERITS AND DEMERITS OF HOME LOAN}

\section{MERITS}

The lower interest rate is affordable for the common man and they can repay the whole interest rate in easy monthly instalments. 
ISSN 2349-2325 (Online); DOI: 10.16962/EAPJFRM/issn. 2349-2325/2015; Volume 9 Issue 4 (2018)

* The buying home is now easier for the lower income group society, that was only dream for them, as they have not bulk liquidity.

The borrower can get rebate in income tax as it is the only debt in which government has allowed some rebate under Sec.24 and under Sec.80C

\section{DEMERITS}

The borrower is always in pressure and if he/she does not repay the credit, the property can be lapsed.

Debt is good economic condition works as booster for development, but on the contrary, it provides poison in bad condition.

\subsection{HOUSING FINANCE PROBLEMS AND SOLUTIONS}

A numbers of problems are faced by the customers in Indian housing finance market. Hence for the convenience of the study the problems and solutions of housing finance are as follows:

\section{1) Early application rejection}

Many housing loan applications are rejected at the very outset. The reasons are many. Some get rejected because there is a wide difference between what the borrower is seeking and what the lender is able to sanction on the basis of the borrower's eligibility. Also, the loan application could fail to qualify on parameters like age, experience, income, credit score, and document checklist, negative technical or legal verifications reports etc.

Remedy: To avoid getting the application rejected at the first stage, pre-check the eligibility requirements of the bank and apply with our profile and requirements in mind. Also, providing accurate information and supporting documents will help through the preliminary process smoothly.

\section{2) Sanctioned amount less than expected}

The amount of home loan that the bank sanction is on the basis of the borrower's repayment capacity. But that is not the sole criterion. The lender may also probe on other parameters like financial history, credit score, unpaid loans, monthly average bank balance, bounced cheques, employment stability etc. The lender takes the final call on lending only after considering all these factors. 
ISSN 2349-2325 (Online); DOI: 10.16962/EAPJFRM/issn. 2349-2325/2015; Volume 9 Issue 4 (2018)

Remedy: To increase your loan eligibility, club the income of our working partner, spouse or parent to our own. We can also present our additional income-rental income or bonus for improve the loan eligibility.

\section{3) Voluminous paperwork}

The documentation involved in a housing loan process can be tedious for many applicants. Housing loan is a versatile process that requires a careful review of a huge bunch of documents. The process itself can often be cumbersome, unless have a clear understanding of why a certain document is important, paper work is essential, irrespective of your credit score and income level.

Remedy: It is important to be aware of the banks process and procedures. We should know why banks seek certain documents. So go through the standard home loan checklist for the banking product we are applying for and also, if there have been any discrepancies in the past ,be ready with supporting documents.

\section{4) Legal valuation of the property/asset}

Banks outsource to third parties the work of doing technical and legal valuation of the property/asset for which a loan is sought. This third-party agency evaluates the asset on the basis of its own set of parameters and then assigns value. The lender funds only a certain amount or percentage of this value. So, there might be a gap between what we want and what the lender can fund.

Remedy: To prevent any confusion over the real value of a property, get its valuation done by a valuer before approaching a bank for loan. It is advisable to get the market rate of the property ascertained by two valuers.

\section{5) Bias between existing and new borrowers}

Among the most common issues that an existing borrower faces that of a discrepancy in interest rate charged from them vis-à-vis a new borrower. The home loan interest rate offered is linked to the base rate (now known as marginal cost of funds based lending rate or MLCR). An existing borrower would have been charged an interest rate at the base rate prevailing at the time he had applied for his loan. That rate might have been different from the one charged from the new borrower, depending on the lending rate situation at present.

Remedy: If we switch to another lender, it treats us like a new borrower and offers us the benefit of the lower interest rate prevailing in the market. It is crucial for to understand the real merits of moving our loan to a new bank before taking such a 
ISSN 2349-2325 (Online); DOI: 10.16962/EAPJFRM/issn. 2349-2325/2015; Volume 9 Issue 4 (2018)

decision. Remember, most lenders charge

0.5-1.00 per cent of the outstanding loan amount if we are moving our existing loan it.

\subsection{Causes of Home Loan Default}

Home loan default is an unfortunate event in any borrower's life. It can be caused by a variety of reasons. What we must understand is that sometimes we cannot control external factors. As a defaulter, there is no need to panic and get into depression. There are rules and procedures that can be followed to recover from a home loan default. But first, let us look at the causes of home loan default.

\section{1) Loss of job}

We may default on our home loan if we are out of a job. Economic conditions and recessions can result in loss of jobs. This situation is out of our control and we should not panic if this happens. Loss of job result in a results in a break in the regular source of income which can hamper our ability to pay home loan EMIs.

\section{2) Going out of business}

If we have a business, we may run into trouble due to some factors which may disrupt our source of income. This may cause result in non - payment of home loan EMI. If we are not able to recover in
2 - 3 months and are not able to pay the EMIs, it may result in Home Loan Default.

\section{3) Major illness}

Illness can affect anyone anytime. It is beyond our control if we get critically ill. This may result in some time off our job and stop our income temporarily. During this time if we miss 3 EMI payments, it will lead to Home Loan Default.

\section{4) Overestimation of future income}

Let us say we thought we would be able to repay a higher EMI as our income would increase in the future. However, we might be wrong in estimating our future income. We might overestimate our income which may create a situation of financial stress. If the higher EMI becomes a burden as our income result in Home Loan default.

\section{5) Death or critical damage}

The most unfortunate event would be untimely death of a person. If we are critically damaged or dead due to some reasons we won't be able to repay the loan. This will result in home loan default.

\subsection{HOW BANKS REACT TO HOME LOAN DEFAULT}

Banks don't seize our assets as soon as we default. Banks don't want to go through the hassle of disposing of our assets to get their money back. If given a choice, banks 
ISSN 2349-2325 (Online); DOI: 10.16962/EAPJFRM/issn. 2349-2325/2015; Volume 9 Issue 4 (2018)

would stay away from it. Banks do not resort to such extreme measures when such defaults occur.

The government passed the Securitisation and Reconstruction of Financial Assets and Enforcement of Security Interest Act (SARFAESI) in 2002 which protects lenders and gives them the right to seize all non - performing assets in case of default. However, banks are not keen on using this law to take over our assets. We can settle our default and convince the bank that we will never default again. Banks would like this rather than auctioning off our property.

\section{$>$ Notification to Defaulters}

When we miss an EMI payment, banks may not react to it. But when we miss two consecutive EMI payments, banks will send we a formal notice stating that we have missed two consecutive EMI payments and strict action will be taken against us if we continue to do so.

\section{$>$ Tax implications}

In the unfortunate event that our property is sold by the bank, we might be liable to short term or long term capital gains as applicable to us. If the property is sold within 3 years of acquisition, any profit made on the sale will be given to us and will be taxed at the short term capital gain rate applicable to us. If it is sold after 3 years, we can benefit from tax exemption under section 54 by investing the capital gains in another house/property or NHAI/REC bonds. If the selling of property results in an amount less than the outstanding loan, we will have to pay the shortfall to the bank.

\section{$>$ Credit score Takes a Hit}

Financial Institutions have to report all credit linked transactions including default to Credit Information Bureau like CIBIL. If we default on our home loan that will also be reported to bodies like CIBIL. Such a report of default will adversely affect our credit score and credit history. This will affect our ability to avail future credit in the form of loans and credit cards. Thus we should make sure to avail a default if we don't want a bad credit history and score.

\subsection{How can we tackle such a situation?}

Firstly, we should not panic and keep calm. Missing one or two payments does not mean that the bank will seize our assets. However, we should be concerned if we miss our third consecutive EMI payments. If such a situation occurs be ready to explain our story to the bank. Below are the few options that we can use in case of default. 
ISSN 2349-2325 (Online); DOI: 10.16962/EAPJFRM/issn. 2349-2325/2015; Volume 9 Issue 4 (2018)

\section{Restructuring the loan}

If we feel that not paying the recent EMIs is a temporary hiccup, we should go to the bank and explain this. Provide the bank with relevant documents and enough information that shows that we have never defaulted on loan payments before. Show the bank of any credit card statements that we have been paying regularly. If the bank feels that the situation is temporary, it may extend the tenure of the loan which will bring down the EMI. Once we are back in a comfortable situation, we should renegotiate the terms back to the original one.

\section{Selling the home yourself}

As mentioned above banks are not in the business of selling of property and they don't want to go through the hassle of selling our house. Instead, we can relieve the bank and sell our home our self. Thus, we should ensure to get the best price possible so that we can easily repay the loan. After paying off the loan, if we are left with some money, we can use it purchase a more economical house.

\section{Defer the Payment}

If we believe that the drought is over and there will be cash inflow in the near future, we can try to convince our bank to give us a grace period. We can ask for a temporary relief period of few months. If the bank allows it, we can make the outstanding payments as soon as we get the money.

\section{Part Payment if Possible}

If there is any way for us to make part payments, we should talk to the bank and plan to do so. We may borrow money from our friends and family and try to make part payments. This way banks might not foreclose our loan and might not seize our property.

\section{Selling off our Investments}

Another option we have sell our existing investments such as equities, mutual funds, fixed deposits, etc. to pay off the loan and preventing the loss of our house. This is a difficult decision which means that we should analyse our current situation and future financial goals before selling investments

\subsection{Analysis and Interpretation: (Ref Table- 1)}

From the above table it can be interpretated that

1. Much of the loan applications are from Male customers. $(70 \%)$

2. The loan have been availed by the age group 30-40 (44\%)

3. The government and the professionals are the people who have availed the loan from SBI 
ISSN 2349-2325 (Online); DOI: 10.16962/EAPJFRM/issn. 2349-2325/2015; Volume 9 Issue 4 (2018)

4. The persons who have availed the loan are graduates and post graduates, whose annual income is more than 2,50,000 ( $40 \%)$

5. The monthly installment paid ranges from $10000-20000$ by maximum customers $(50 \%)$

6. Customers agreed that, the value added services provided by the SBI have made them choose SBI for their loan. (48\%)

7. Customers argued that the services provided by the employees are not so satisfactory. The employees are not so quick in their response. ( $52 \%$ )

8. The overall satisfaction level of the customer is good, but even then, they are facing some other problems in the loan disbursement process. (40\%)

Table value of chi square for 1 degree of freedom @ 5\% level of significance is

\subsection{1}

Since the calculated value is less than the table value. Null hypothesis is accepted. Hence alternative hypothesis is rejected .Hence proved that customers are not satisfied with the home loan provided by SBI. They need certain modification in the loan process. (Ref Table- 2)

\subsection{FINDINGS:}

1. The documentation process is very lengthy. Due to verifying the documents of the person and actual property owner.

2. From the data collected it is found that the bank provides various types of home loans along with floating rates of interest.

3. Home loan is the familiar product to among the most of respondents of the bank.

4. More number of respondent have preferred home loan, because of low interest rate in the bank.

5. $48 \%$ of the respondents have taken home loan products because of value added service which is provided by the bank.

6. Awareness of the home loan products in the bank is little low.

7. The coverage of loan provided by the bank is not much wider to the bank.

8. Delay in loan processing/sanctioning time.

9. There is no transparency in lending practice.

10. The change in the terms and conditions especially with regard to interest rate changes are not being communicated.

11. The reasons for rejecting the loan application are not being informed. 
ISSN 2349-2325 (Online); DOI: 10.16962/EAPJFRM/issn. 2349-2325/2015; Volume 9 Issue 4 (2018)

\subsection{SUGGESTIONS:}

1. The bank should reduce the lengthy procedures of documentation process.

2. Nowadays there are many banks or financial institutions coming up with different schemes. So SBI have to go for different competitive schemes for different income level groups to attract the customer.

3. Improve the quality of service providing by the bank.

4. For increase customer's strength of the bank, interest rate is decreasing at little lower.

5. It is recommends to increase value added services to customers of the bank.

6. Provide awareness of home loan products through campaigns, advertisements etc.

7. The coverage of the loan providing of the bank is wider up to the below income level of customers of the bank.

8. Remove the problem faced in transferring of property to loan taken process in the bank.

9. The customers of the SBI suggested that the loan processing/sanctioning time should be reduced further.

10. There should be uniformity in loan sanction procedure, interest rate structure among the various lenders.
11. The changes in the terms and conditions especially with regard to interest rate, the concerned customers should be informed.

12. SBI should inform the reasons for rejecting the loan application. This will help the applicants in rectifying their mistake.

\subsection{CONCLUSIONS:}

Housing finance is comparatively a new concept in the finance sector of India. It is developed rapidly during the last two decades due to the enthusiastic interest of Government of India to reduce the housing problem of the country. Housing finances are blooming in nowadays. Due to the increase standard of living of the customers, the demand of loans is also increased. The income earnings of the customers are increased due to LPG era come to force. And due to the LPG era more opportunities are got by private players.

The banking sectors reforms have gained the sharpen improvements in the financial health of banks in capital adequacy asset quality. The housing finance has bright future in the coming years. The tax benefits and other incentives by government and commercial banks work as the driving force of housing finance. 
ISSN 2349-2325 (Online); DOI: 10.16962/EAPJFRM/issn. 2349-2325/2015; Volume 9 Issue 4 (2018)

For the survival in the market banks are introduced innovative products to customers. Home loan is one of the products provided by the different banks. Here SBI banks also one of the biggest home loans provided in India.

This study mainly concentrates the problems faced by customers in obtaining the home loans. And also the satisfaction level of customers about home loans and service provided by the bank.

\section{Bibliography:}

Books:

B.S Raman (2003) "Law and practices of Banking”

Naik D.D (1981) "Housing Finance pamphlet 163" Mumbai: Commerce publication, Page No $1,12,15$, and 18

Versgney,P.N.(1997),'Banking Law and Practices",New Delhi: Sultan Chan \& sons, $34^{\text {th }} \mathrm{Ed}$.

\section{Articles:}

De Paul Singh (2001) "Consumer Behaviour and Bank Retail products an Analysis “

\section{LIST OF TABLES}

Table- 1- Analysis and Interpretation:

\begin{tabular}{|l|l|l|}
\hline Gender & $\begin{array}{l}\text { Number of } \\
\text { Respondents }\end{array}$ & $\begin{array}{l}\text { Percentages } \\
(\boldsymbol{\%})\end{array}$ \\
\hline Male & 35 & 70 \\
\hline
\end{tabular}

Dr Rangarajan C (2001) "The financial system of India"

Favilukis, Ludvigson and Nieuwerburgh (2011) "The macroeconomic effects of housing wealth, housing finance and limited risk sharing in general equilibrium."

Housing Policy Department, NABH (2009) "A study on the local impact of home building in a typical metro area."

P.K.Manoj (2004), “The growth and development of housing finance system in India."

\section{Websites:}

www.housingfinance.org/housing-finance https://www.dhfl.com/aadharhousing.com https://www.bankbazaar.com/homeloan.html https://homeloans.sbi/ https://www.tatacapital.com/homeloans.htm www.paisabazaar.com/Home_Loan https://www.karvy.com/ 
ISSN 2349-2325 (Online); DOI: 10.16962/EAPJFRM/issn. 2349-2325/2015; Volume 9 Issue 4 (2018)

\begin{tabular}{|c|c|c|}
\hline Female & 15 & 30 \\
\hline Total & 50 & 100 \\
\hline Age Group & $\begin{array}{l}\text { Number of } \\
\text { Respondents }\end{array}$ & $\begin{array}{l}\text { Percentage } \\
(\%)\end{array}$ \\
\hline $20-30$ & 12 & 24 \\
\hline $30-40$ & 22 & 44 \\
\hline $40-45$ & 10 & 20 \\
\hline $45-50$ & 4 & 8 \\
\hline Above 50 & 2 & 4 \\
\hline Total & 50 & 100 \\
\hline Occupation & $\begin{array}{l}\text { Number of } \\
\text { Respondents }\end{array}$ & $\begin{array}{l}\text { Percentages } \\
(\%)\end{array}$ \\
\hline Businessman & 10 & 20 \\
\hline Professional & 14 & 28 \\
\hline $\begin{array}{l}\text { Govt. } \\
\text { Employee }\end{array}$ & 20 & 40 \\
\hline $\begin{array}{l}\text { Self } \\
\text { Employed }\end{array}$ & 6 & 12 \\
\hline Total & 50 & 100 \\
\hline $\begin{array}{l}\text { Education } \\
\text { Qualificatio } \\
\text { n }\end{array}$ & $\begin{array}{l}\text { Number of } \\
\text { Respondents }\end{array}$ & $\begin{array}{l}\text { Percentages } \\
(\%)\end{array}$ \\
\hline Below SSLC & 6 & 12 \\
\hline $\begin{array}{l}\text { PUC/ITI/Dip } \\
\text { loma }\end{array}$ & 10 & 20 \\
\hline Graduate & 14 & 28 \\
\hline $\begin{array}{l}\text { Post } \\
\text { Graduate }\end{array}$ & 20 & 40 \\
\hline Total & 50 & 100 \\
\hline $\begin{array}{l}\text { Annual } \\
\text { Income }\end{array}$ & $\begin{array}{l}\text { Number of } \\
\text { Respondents }\end{array}$ & $\begin{array}{l}\text { Percentage } \\
(\%)\end{array}$ \\
\hline $\begin{array}{l}50000- \\
100000 \\
\end{array}$ & 6 & 12 \\
\hline $\begin{array}{l}100000- \\
150000\end{array}$ & 10 & 20 \\
\hline $\begin{array}{l}150000- \\
250000\end{array}$ & 14 & 28 \\
\hline $\begin{array}{l}\text { Above } \\
250000\end{array}$ & 20 & 40 \\
\hline Total & 50 & 100 \\
\hline $\begin{array}{l}\text { Monthly } \\
\text { Instalment } \\
\text { Paid }\end{array}$ & $\begin{array}{l}\text { Number of } \\
\text { Respondents }\end{array}$ & $\begin{array}{l}\text { Percentages } \\
(\%)\end{array}$ \\
\hline Below 5000 & 6 & 12 \\
\hline $5000-10000$ & 9 & 18 \\
\hline $10000-20000$ & 25 & 50 \\
\hline More than & 10 & 20 \\
\hline
\end{tabular}




\begin{tabular}{|c|c|c|c|}
\hline 20000 & & & \\
\hline Total & 50 & 100 & \\
\hline $\begin{array}{l}\text { Tenure of } \\
\text { the loan }\end{array}$ & $\begin{array}{l}\text { Number of } \\
\text { Respondents }\end{array}$ & $\begin{array}{l}\text { Perc } \\
(\%)\end{array}$ & ntages \\
\hline $0-3$ & 6 & 12 & \\
\hline $3-5$ & 8 & 16 & \\
\hline $5-7$ & 26 & 52 & \\
\hline More than 7 & 10 & 20 & \\
\hline Total & 50 & 100 & \\
\hline $\begin{array}{l}\text { Factors } \\
\text { influenced to } \\
\text { choose SBI }\end{array}$ & $\begin{array}{l}\text { Number of } \\
\text { Respondents }\end{array}$ & $\begin{array}{l}\text { Perc } \\
(\%)\end{array}$ & ntages \\
\hline $\begin{array}{l}\text { Interest rate } \\
\text { low }\end{array}$ & 8 & 16 & \\
\hline Tax benefits & 12 & 24 & \\
\hline $\begin{array}{l}\text { Value added } \\
\text { service }\end{array}$ & 24 & 48 & \\
\hline Easy to get & 6 & 12 & \\
\hline Total & 50 & 100 & \\
\hline $\begin{array}{l}\text { Employee } \\
\text { Response in } \\
\text { SBI }\end{array}$ & $\begin{array}{l}\text { Number of } \\
\text { Respondents }\end{array}$ & $\begin{array}{l}\text { Perc } \\
(\%)\end{array}$ & ntages \\
\hline $\begin{array}{l}\text { Quick } \\
\text { responding }\end{array}$ & 8 & 16 & \\
\hline $\begin{array}{l}\text { Not quickly } \\
\text { responding }\end{array}$ & 26 & 52 & \\
\hline $\begin{array}{l}\text { Not } \\
\text { responding in } \\
\text { proper way }\end{array}$ & 12 & 24 & \\
\hline Can't say & 4 & 8 & \\
\hline Total & 50 & 100 & \\
\hline $\begin{array}{l}\text { Customer's } \\
\text { satisfaction } \\
\text { level }\end{array}$ & $\begin{array}{l}\text { Number of } \\
\text { Respondents }\end{array}$ & $\begin{array}{l}\text { Perc } \\
(\%)\end{array}$ & ntages \\
\hline Very Good & 8 & 16 & \\
\hline Good & 25 & 50 & \\
\hline Moderate & 10 & 20 & \\
\hline Poor & 3 & 6 & \\
\hline Very Poor & 4 & 8 & \\
\hline $\begin{array}{l}\text { Problems } \\
\text { faced in } \\
\text { SBI }\end{array}$ & $\begin{array}{l}\text { Number } \\
\text { Respondents }\end{array}$ & of & $\begin{array}{l}\text { Percen } \\
\text { tages } \\
(\%)\end{array}$ \\
\hline Applying & 4 & & 8 \\
\hline $\begin{array}{l}\text { Document } \\
\text { process }\end{array}$ & 5 & & 10 \\
\hline $\begin{array}{l}\text { Property } \\
\text { documents }\end{array}$ & 7 & & 14 \\
\hline
\end{tabular}


ISSN 2349-2325 (Online); DOI: 10.16962/EAPJFRM/issn. 2349-2325/2015; Volume 9 Issue 4 (2018)

\begin{tabular}{|l|l|l|}
\hline $\begin{array}{l}\text { Disbursemen } \\
\mathrm{t} \quad \text { or } \\
\text { transferring }\end{array}$ & 14 & 28 \\
\hline Others & 20 & 40 \\
\hline Total & 50 & 100 \\
\hline
\end{tabular}

Source: Survey

\section{Table- 2- Test Application}

Chi square Test

H0:Customers are not satisfied with CRM provided by SBI toward home loan

H1: Customers are satisfied with CRM provided by SBI toward home loan

\begin{tabular}{|l|l|l|l|l|l|l|}
\hline Responses & Observed & Expected & $(\mathrm{O}-\mathrm{E})$ & $(\mathrm{O}-\mathrm{E})^{\wedge} 2$ & $(\mathrm{O}-\mathrm{E})^{\wedge} 2 / \mathrm{E}$ & Values \\
\hline Yes & 15 & 20 & -5 & 25 & $25 / 20$ & 1.25 \\
\hline No & 35 & 30 & +5 & 25 & $25 / 30$ & 0.833 \\
\hline
\end{tabular}

Calculated Value $=\mathbf{2 . 0 8 3}$

Degree of freedom n-1 i.e 2-1=1 